\title{
Bacterial Canker on Kiwifruit in Italy: Anatomical Changes in the Wood and in the Primary Infection Sites
}

\author{
Marsilio Renzi, Paul Copini, Anna R. Taddei, Antonio Rossetti, Lorenzo Gallipoli, \\ Angelo Mazzaglia, and Giorgio M. Balestra
}

First, fourth, fifth, sixth, and seventh authors: Dipartimento di Scienze e Tecnologie per l'Agricoltura, le Foreste, la Natura e l'Energia (DAFNE), Università della Tuscia, 01100 Viterbo, Italy; second author: Forest Ecology and Forest Management Group, Centre for Ecosystem Studies, Wageningen University, P.O. Box 47, 6700AA Wageningen, The Netherlands; and third author: Centro Interdipartmento di Microscopia Elettronica (CIME), Università della Tuscia, 01100 Viterbo, Italy. Accepted for publication 27 May 2012.

\begin{abstract}
Renzi, M., Copini, P., Taddei, A. R., Rossetti, A., Gallipoli, L., Mazzaglia, A., and Balestra, G. M. 2012. Bacterial canker on kiwifruit in Italy: Anatomical changes in the wood and in the primary infection sites. Phytopathology 102:827-840.

The bacterial canker of kiwifruit caused by Pseudomonas syringae pv. actinidiae is a severe threat to kiwifruit production worldwide. Many aspects of $P$. syringae pv. actinidiae biology and epidemiology still require in-depth investigation. The infection by and spread of $P$. syringae pv. actinidiae in xylem and phloem was investigated by carrying out artificial inoculation experiments with histological and dendrochronological analyses of naturally diseased plants in Italy. We found that the bacterium can infect host plants by entering natural openings and lesions. In naturally infected kiwifruit plants, $P$. syringae pv. actinidiae is present

in the lenticels as well as in the dead phloem tissue beneath the lenticels, surrounded by a lesion in the periderm which appears to indicate the importance of lenticels to kiwifruit infection. Biofilm formation was observed outside and inside plants. In cases of advanced stages of $P$. syringae pv. actinidiae infection, neuroses of the phloem occur, which are followed by cambial dieback and most likely by infection of the xylem. Anatomical changes in wood such as reduced ring width, a drastic reduction in vessel size, and the presence of tyloses were observed within several infected sites. In the field, these changes occur only a year after the first leaf symptoms are observed suggesting a significant time lapse between primary and secondary symptoms. It was possible to study the temporal development of $P$. syringae pv. actinidiae-induced cambial dieback by applying dendrochronology methods which revealed that cambial dieback occurs only during the growing season.
\end{abstract}

The present worldwide spread of the bacterial canker of kiwifruit (Actinidia spp.) caused by Pseudomonas syringae pv. actinidiae indicates that the disease has reached truly pandemic proportions. This pathogen was first recorded in China in 1984 (20), to be later identified in Japan (63) and in China (67). It was first found in Italy in 1992 (49). Since 2008, P. syringae pv. actinidiae has spread with devastating virulence throughout Europe, appearing initially in Italy in $2008(2,3)$ and then in France in 2010 (64) and in Portugal (4). Meanwhile, P. syringae pv. actinidiae was also recorded in New Zealand (19) and in Chile (1) in 2010, and in Australia (8), Spain (5), Switzerland (18), and Turkey (7) in 2011 and 2012. Although some other kiwifruit pathogens, like Phialophora and Phytophthora, were recorded, they are not as aggressive as $P$. syringae pv. actinidiae $(15,16,28,39)$.

$P$. syringae pv. actinidiae is capable of infecting the internal tissue of kiwifruit (51). It causes distinctive symptoms in the organs above-ground: brown spots surrounded by a yellow halo on the leaves, dark coloration and detachment of the floral organs (buds and flowers), dieback of the twigs, leaders and canes, collapse of the fruit, and typical canker formation on the vines and trunks. In the final stage of $P$. syringae pv. actinidiae infection, which can occur as early as a few months after observation of the first symptoms, copious white opalescent or dark red exudates are excreted from the bark (Fig. 1).

Corresponding author: G. M. Balestra; E-mail address: balestra@unitus.it

http://dx.doi.org/10.1094/PHYTO-02-12-0019-R

(c) 2012 The American Phytopathological Society
To curb the devastating effects of $P$. syringae pv. actinidiae on kiwifruit plants it is of paramount importance to understand the biological cycle and infection mechanism of this pathogen. Previous studies, carried out mainly in Japan, have indicated that (i) P. syringae pv. actinidiae moves in the tissue from leaf lesions through the midrib and the petiole to the stems and branches causing typical cankers; (ii) after artificial inoculation, the optimal temperature for the development of symptoms for bacterial growth on new cane ranges between 10 to $20^{\circ} \mathrm{C}$; (iii) $P$. syringae pv. actinidiae overwinters in diseased tissue and the disease appears more severe in very windy areas; and (iv) the disease symptoms that appear in late winter/early spring on trunks and branches depend primarily on the level of inoculum during the previous fall and early winter (52-56).

Recently, research into the outbreak of $P$. syringae pv. actinidiae in Italy has produced further knowledge about the life cycle of the pathogen: (i) the pathogen is able to survive at high temperatures, to and beyond $25^{\circ} \mathrm{C}$; (ii) during summer, it is extremely difficult to isolate the bacterium even from the foliar spots which occurred at the beginning of spring; (iii) $P$. syringae pv. actinidiae is unable to survive for the duration on an entire vegetative season outside of kiwifruit organs; (iv) the pathogen can reach the roots and overwinter; (v) the damage caused by $P$. syringae pv. actinidiae increases cells of other pathogens like $P$. syringae pv. syringae and/or $P$. viridiflava, which are present simultaneously $(6,33,34,44,47,61,65,69)$.

According to the knowledge we possess at present, $P$. syringae pv. actinidiae infection appears to occur through natural openings and lesions; however, this has not yet been confirmed experimentally. Furthermore, previous studies aimed to determine which of the vascular systems (xylem or phloem) are colonized and how 
plant tissues may be invaded by $P$. syringae pv. actinidiae have proven inconclusive to date $(34,51,52,55,56)$. The temporal aspects of $P$. syringae pv. actinidiae infection have not been studied as yet and might provide valuable information regarding the activity and spread of $P$. syringae pv. actinidiae. Therefore in this study, anatomical, dendrochronological and histological examination of naturally $P$. syringae pv. actinidiae-infected kiwifruit plantations were combined with artificial inoculation experiments aimed at determining how, where, and when kiwifruit plants are likely to become infected. The main aims were to assess (i) whether both the phloem and xylem are affected by $P$. syringae pv. actinidiae and whether dendrochronologic techniques can be used to study the temporal development of $P$. syringae pv. actinidiae infection by dating $P$. syringae pv. actinidiae-induced changes in anatomical alterations of the wood variables (ring width and vessel characteristics) and of cambial dieback, and (ii) whether this bacterial pathogen can effectively infect kiwifruit plants through natural openings such as stomata, trichomes, lenticels, and lesions.

\section{MATERIALS AND METHODS}

Naturally $P$. syringae pv. actinidiae-infected kiwifruit plants. The zone singled out for investigation was Cisterna di Latina an agricultural district in the southern coastal area of the Lazio Region, in central Italy, the most important for kiwifruit cultivation in Italy. It comprises over 8,000 ha of kiwifruit plantations of both the green kiwi (A. deliciosa) and yellow variety ( $A$. chinensis). Here the outbreak of the bacterial canker disease was recorded in 2008 (2) and currently at present over $30 \%$ of kiwifruit in the orchards are affected by this pathogen.

Sampling and sample preparation. In order to study whether the lenticels permit the entry of the bacterium into the underlying phloem and xylem and to determine when cambial dieback occurs, cross sections were taken from 10 plants ('Hayward' and 'Hort 16A') at $1 \mathrm{~m}$ stem height during the 2011 growing season. The kiwifruit plants had been infected since 2010 .

To ascertain whether the changes in the anatomy of the wood caused by $P$. syringae pv. actinidiae infection occur within 1 year of insurgence of the initial symptoms, cross sections of three important commercial cultivars of Actinidia spp., Hayward (A. deliciosa), Hort 16A, and Jin Tao (A. chinensis), were taken during the growing season. Ten healthy and 10 naturally $P$. syringae pv. actinidiae-infected samples were collected from 3- and 4-year-old plants at the $1 \mathrm{~m}$ point of the stem. The infected plants had presented typical $P$. syringae pv. actinidiae symptoms during the previous growing season (2010). To verify whether the symptoms were $P$. syringae pv. actinidiae-induced, samples of leaves, twigs, leaders, and branches for each kiwifruit plant examined were also taken and submitted to routine phytobacteriological analysis as described below.

Polymerase chain reaction (PCR)-based confirmation of $\boldsymbol{P}$. syringae pv. actinidiae in diseased tissue. In detail, small fragments $\left(2 \mathrm{~mm}^{2}\right)$ of diseased tissue were excised and transferred onto nutrient agar (NA) plates and incubated at $27^{\circ} \mathrm{C}$ for $48 \mathrm{~h}$. Then, each of the bacterial colonies obtained was transferred to new NA plates in conditions identical to those described above. Approximately $2 \times 10^{9}$ cells were used for DNA extraction using the PureLink Genomic DNA kit (Invitrogen) following the manufacturer's instructions for Gram-negative bacteria. The concentration of the eluted DNA was calculated using a fluorometric device (QubitTM, Invitrogen, Life Technologies Italia, Monza, Italy) set to a final concentration of $50 \mathrm{ng} / \mu \mathrm{l}$ with $\mathrm{TE}$ buffer (10 mM Tris- $\mathrm{HCl}, 1 \mathrm{mM}$ EDTA, $\mathrm{pH}$ 8.0) and kept at $-20^{\circ} \mathrm{C}$ until required.

Specific PCRs aimed at recognizing $P$. syringae pv. actinidiae were carried out using both the PsaF1 (5'-TTTTGCTTTGCA CACCCGATTTT-3') and PsaR2 (5'-CACGCACCCTTCAATC
AGGATG-3') primer pairs described by Rees-George and colleagues (46) and the F (5'-CACGATACATGGGCTTATGC-3') and R (5'-CTTTTCATCCACACACTCCG-3') primer pairs described by Koh and Nou (27). Each reaction consisted of a $50 \mu$ total volume mixture with $25 \mu$ l of GoTaq Colorless Master Mix 2X (Promega Corporation, WI), $1 \mu$ of template DNA, $1 \mu \mathrm{M}$ of each primer, and sterile distilled water to the final volume. Amplifications were carried out on a C1000 gradient thermal cycler (Bio-Rad Laboratories s.r.l., Milan, Italy) under the conditions described by the authors.

A negative control (no template DNA) was included in each batch of PCRs. The amplification products were detected by electrophoresis of $5 \mu \mathrm{l}$ of each amplification mixture in a $2 \%$ agarose gel in $1 \times$ Tris-acetate-EDTA buffer. Gels were stained with GelRedTM (Biotium Inc., CA). At least three replicate PCR amplifications were carried out independently for each strain.

Microscopy. Then 20- to $25-\mu \mathrm{m}$-thick transverse sections were cut from all samples using a sliding microtome (G.S.L.-1 microtome, WSL, Birmensdorf, Switzerland). All sections were stained with a blue safranin-astra solution for $5 \mathrm{~min}$ to obtain better contrast between cell walls and cell lumen. The staining mixture was prepared by adding $40 \mathrm{mg}$ of safranin and $150 \mathrm{mg}$ of astra blue to a solution of $100 \mathrm{ml}$ of demineralized water with $2 \mathrm{ml}$ of acetic acid. Following dehydration in graded series of ethanol (50-95-100\%), the samples were rinsed with xylol, mounted in Canada balsam, and dried at $60^{\circ} \mathrm{C}$ for $15 \mathrm{~h}$. Pictures with a spatial resolution of 228.26 pixels $/ \mathrm{mm}$ were taken using a digital camera (DFC 320, Leica, Cambridge, UK) mounted on a microscope (DM2500, Leica) using Leica imaging software (version 3.6.0).

Dendrochronological analyses. Tree ring characteristics such as ring width, vessel size, and vessel density carry information on tree vitality, productivity, and physiological functioning (21). Ring width can be used as a proxy for tree vitality and productivity. Vessel size and density may vary due to changing environmental or internal circumstances (21), affecting physiological functioning of the plant. Dating of drastic changes in tree ring parameters is a common tool in dendrochronology to trace various temporal phenomena affecting plant growth and thus might be used to reconstruct the spread of $P$. syringae pv. actinidiae over time (21).

Ring width, vessel sizes, and vessel density were measured along one radius using ImageJ software (version $1.40 \mathrm{~g}$, Wayne Rasband, NIH). Ring width was measured in micrometers. Vessel size $\left(\mu \mathrm{m}^{2}\right)$ was measured per tree ring using a fixed tangential width of $2 \mathrm{~mm}$. To measure vessel sizes semi-automatically, cell lumen and cell tissue were first segmented using the threshold function followed by erosion and dilatation of 2 pixels to remove small objects and irregularities. Finally, to check the precision of the measurements the masks belonging to individual vessels were overlaid with the original picture and adapted whenever necessary. To test whether drastic changes in maximum vessel size are caused by infection, the 10 biggest vessels per tree ring were analyzed separately. Vessel density was assessed by calculating the number of vessels per square millimeter (vessels $/ \mathrm{mm}^{2}$ ) per tree ring. A further analysis of variance (ANOVA) measurement was carried out to test differences in variables from year to year. In addition, one-way ANOVA was used to study differences occurring in 2010, the year when clear symptoms of $P$. syringae pv. actinidiae infection were recorded.

The year and season during which $P$. syringae pv. actinidiaeinflicted cambial dieback occurred were determined and traced by dendrochronological dating of the tree rings where cambial dieback and callus-tissue were present (60). The location of cambial dieback and callus formation directly on the tree ring boundary or within the ring itself, provided indications as to whether the cambial dieback had occurred during the dormant period or during the growing season (48). When cambial dieback occurs before the growing season, the dead cambium is located on the 
tree-ring boundary, whereas when it occurs during the growing season, the collapsed cambium is located within the tree ring (50).

Study of lenticels and underlying phloem and xylem tissue. A thin transverse section of the lenticels and the underlying tissue was screened using light microscopy (LM; DM2500, Leica) whenever periderm lesions, dead phloem, cambial dieback, callus formation, tyloses and drastic changes in ring width, vessel size, and vessel density were found (59). By callus we mean meristematic parenchyma cells. Afterwards, lenticels, phloem, and xylem were submitted to routine phytobacteriological procedures and the isolates were submitted to appropriate analyses (phenotypic and molecular) to verify the presence of $P$. syringae pv. actinidiae in these tissues $(27,46,63)$.

Artificial $P$. syringae pv. actinidiae-infected kiwifruit plants. Plant material, bacterial strain, inoculum preparation. Healthy kiwifruit seedlings (45 per each cultivar) were placed in a growth chamber in 20-cm-diameter pots containing a sterilized mix of soil/sand/peat $(2: 1: 1, \mathrm{vol} / \mathrm{vol})$ and watered daily by drip-irrigation. A mineral solution (NPK 20-20-20+B+Cu+Fe+Mn+Mo+Zn 1-530-10-10-10, respectively) at $2 \mathrm{~g} /$ liter was added weekly to the pots to maintain optimum nutritional conditions. Temperatures were maintained at $25^{\circ} \mathrm{C}$ for $16 \mathrm{~h}$ (light) and at $15^{\circ} \mathrm{C}$ for $8 \mathrm{~h}$ (darkness); relative humidity (RH) was maintained at 60 to $70 \%$. The plants were approximately $40 \mathrm{~cm}$ high at the moment of their artificial bacterial infection.

For this study, a known pathogenic strain of $P$. syringae pv. actinidiae CFBP 7286 was used. It was isolated from infected $A$. chinensis 'Hort 16A' kiwifruit plants in 2008, in the Cisterna di Latina district (province of Latina, Lazio Region). In this study the bacterial strain was cultured on King's medium B (KB) (26) and its resistance to an antibiotic (rifampicin) was determined by applying the techniques described by Nishizawa and colleagues (40). Bacterial cells were removed from KB plates and suspended in $0.01 \mathrm{M}$ potassium phosphate buffer $(\mathrm{pH} \mathrm{7.0)}$. The buffer suspension was obtained from 24-h-old bacterial culture and adjusted to $10^{7}$ colony-forming units $(\mathrm{cfu}) / \mathrm{ml}$ using a spectrophotometer at $600 \mathrm{~nm}$.

Plant inoculation. The $P$. syringae pv. actinidiae inoculation was carried out using a number of different methods to mimic natural conditions of $P$. syringae pv. actinidiae infection: (i) inoculation by spraying leaves with no injuries; (ii) inoculation by spraying leaves after procuring slight injury (to simulate natural rubbing); and (iii) inoculation by injection at the base of the petiole. Ten plants per cultivar were tested for each inoculation method and a sterile bacteriological saline $(0.85 \% \mathrm{NaCl})$ was applied to five plants by way of negative control. During the experiments ( $4 \mathrm{~h}$ before and $4 \mathrm{~h}$ after each inoculation), the plants were maintained at $95 \% \mathrm{RH}$ level.

$P$. syringae pv. actinidiae inoculation of uninjured plants. The bacterial suspension was sprayed on the kiwifruit plants using a $\mathrm{CO}_{2}$-pressurized hand-held sprayer equipped with a nozzle with a large orifice $(1.4 \mathrm{~mm}$, Tee-Jet 8004$)$ at a pressure of $2.8 \mathrm{~g} / \mathrm{cm}^{2}$ to produce large spray droplets. The spray nozzle was kept close to the plants $(20$ to $30 \mathrm{~cm}$ ) to reduce bacterial migration by aerosol from the application site.

$P$. syringae pv. actinidiae inoculation of injured plants. On two leaves per plant, small lesions (two areas per leaf, of $2 \mathrm{~cm}$ diameter each) were produced on the epidermis by rubbing the leaves. The leaf surfaces were gently rubbed with a Carborundum suspension placed on sterilized paper disks; then the bacterial suspension was sprayed as described before.

$P$. syringae pv. actinidiae inoculation at the injured base of the petiole. Two lateral peduncle insertions per plant were selected. The suspension was injected at the base of the petiole using a sterile needle $(0.25 \times 8 \mathrm{~mm})$. After artificial inoculation, the kiwifruit plants were maintained in a growth chamber and checked daily for $P$. syringae pv. actinidiae symptoms.

Microscopic observation methods (ESEM, SEM and TEM, and LM). Sample collection. In all of the experiments, the samples were taken by using sterile razor blades. Different parts
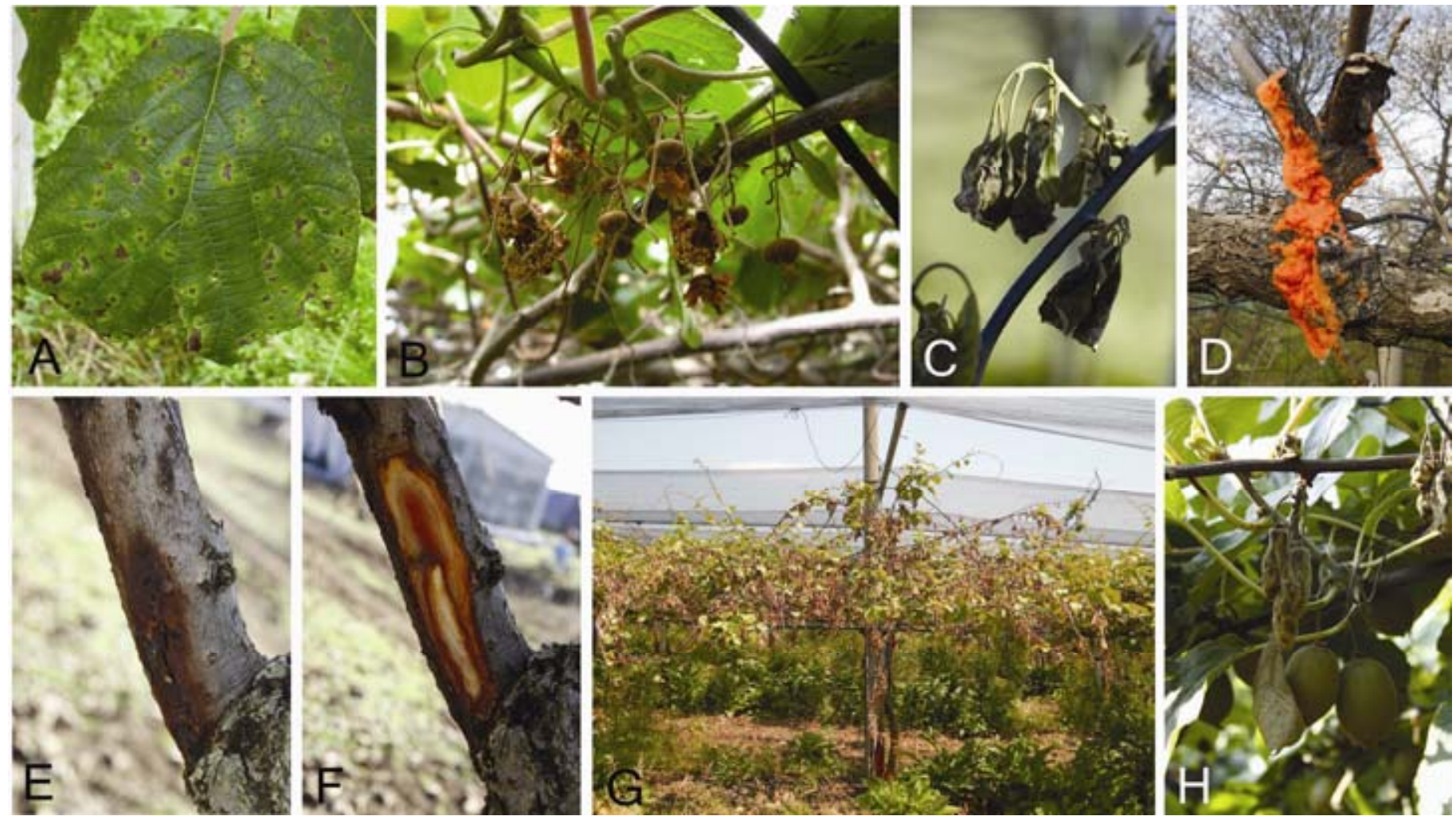

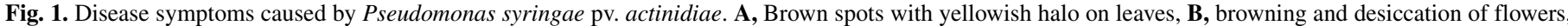

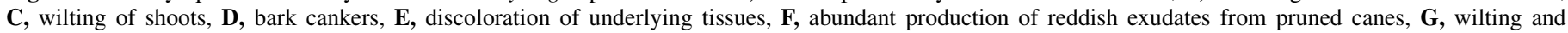
desiccation of fruits, and $\mathbf{H}$, a total view of an infected plant in the plantation. 
of the leaves or petioles that presented obvious symptoms were prepared for scanning electron microscopy (SEM), transmission electron microscopy (TEM), and optical microscopy at the Interdepartmental Centre of Electron Microscopy, Tuscia University, Viterbo, Italy, following conventional procedures. Environmental scanning electron microscopy (ESEM) analyses were carried out at the Ce.M.E.-Centro di Microscopie Elettroniche, CNR, Sesto F.no Firenze, Italy. Leaves were collected from Actinidia spp. plants. Leaf surface morphology was analyzed using a Fei Quanta 200 Environmental Scanning Electron Microscope operating in the low-vacuum mode with the column pressure kept at 1 Torr and applied to a total of four replicate leaves. The ESEM operated at $24.5 \mathrm{kV}$.

Procedures. For the SEM procedure, the samples were fixed with $2.5 \%$ paraformaldehyde $+2.5 \%$ glutaraldehyde, $\mathrm{pH} 7.2$, in $0.1 \mathrm{M}$ cacodylate sucrose buffer overnight at $4^{\circ} \mathrm{C}$. After rinsing each time twice for $30 \mathrm{~min}$ in the same buffer, all of them were post-fixed in cacodylate-buffered $1 \%$ osmium tetroxide for $1 \mathrm{~h}$ and washed twice for $30 \mathrm{~min}$ each in distilled water. The specimens were then dehydrated in a graded ethanol series and dried applying the critical point method availing of $\mathrm{CO}_{2}$ in a Balzers Union CPD 020, sputter-coated with gold in a Balzers MED 010 unit, and observed through a JEOL JSM 5200 electron microscope. Micrographs were taken using a Mamiya camera with TMAX 100 ASA film applied to the microscope.

For LM and TEM examination, samples were fixed and dehydrated as described above. They were then infiltrated and embedded in an Epon-based resin. The embedded plant material was cut using a Reichert Ultra microtome equipped with a diamond knife. For LM analysis, collected sections $(1 \mu \mathrm{m})$ were fixed onto slides, stained with Toluidine blue, and observed using a computer-assisted image analysis system which included a Zeiss (Axiophot) microscope equipped with a color video camera (Axio Cam MRC, Arese, Milano, Italy) and a software package (AxioVision). For the TEM procedure, the sections $(60$ to $80 \mathrm{~nm})$ were fixed on copper grids, stained with uranyl acetate and lead citrate, and observed through a JEOL 1200 EX II electron microscope. Micrographs were acquired using an Olympus SIS VELETA CCD camera equipped with TEM software.

\section{RESULTS}

Naturally $\boldsymbol{P}$. syringae pv. actinidiae-infected kiwifruit plants. Dendrochronological analyses. The dendrochronological analyses of a number of kiwifruit plants that had been symptomatic for 1 year revealed no significant changes in either average vessel size, ring width, or vessel density compared with healthy plants. The average vessel size of all 3-year-old kiwi branches increased from $6,500 \mu \mathrm{m}^{2}$ in 2008 to $21,000 \mu \mathrm{m}^{2}$ in 2010. Average tree ring widths decreased slightly with values of about $3 \mathrm{~mm}$ in 2008 to $1.8 \mathrm{~mm}$ in 2010 . The vessel density per square millimeter stood on average at 15 in 2008 and 20 in 2010 (Fig. 2). The 10 biggest vessels increased on average from approximately $20,000 \mu \mathrm{m}^{2}$ in 2008 to $33,000 \mu^{2}$ in 2010 .

The kiwifruit plants whose symptoms had emerged over a year before presented significantly smaller tree rings (reduced by approximately $75 \%$ ) and vessels (reduced by approximately $50 \%$ ) in 2010 and 2011 compared with previous years. Strips of dead phloem were observed on these plants (Fig. 3) and in several places the infection reached the cambium, which died as a result. The kiwifruit plants reacted by producing a callus tissue and a lesion xylem to overgrow the necrosis during the growing season of 2011 (Fig. 3D). In A. chinensis, the dead phloem and cambium sometimes involved more than half the circumference (Fig. 3G).

The formation of tyloses. The formation of tyloses was frequently observed in $P$. syringae pv. actinidiae-infected $A$. deliciosa and $A$. chinensis plants during the growing season the year after the first symptoms were observed (Fig. 3). Especially in the case of the 'Hayward' (A. deliciosa), clear differences were observed between healthy and infected samples. In healthy samples, few if any tyloses were present, while the infected samples contained many tyloses. In the case of $A$. chinensis, tyloses were mostly present in infected samples but based on visual observation appeared to occur at a lower rate compared with that of A. deliciosa. Tyloses in the A. chinensis cultivar were mainly restricted to the areas where callus tissue occurred. In both the A. deliciosa and A. chinensis cultivars tyloses occurred mostly in the outermost rings in 2009 and 2010.

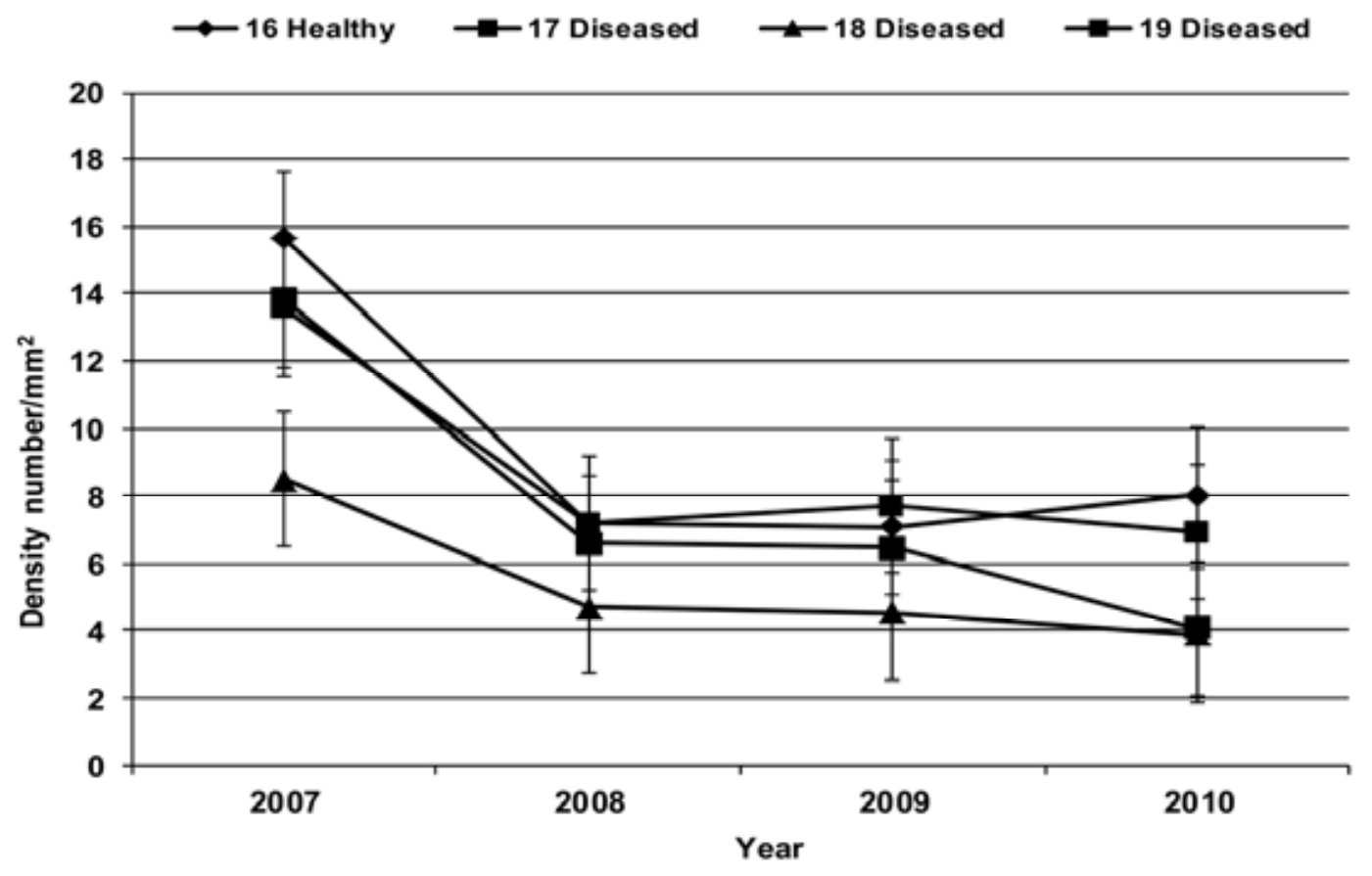

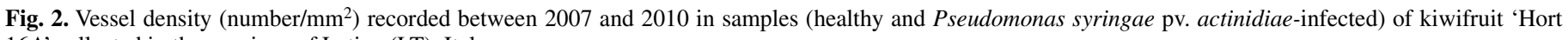
16A' collected in the province of Latina (LT), Italy. 
Lenticels and underlying phloem and xylem. In both species (A. deliciosa, A. chinensis) enlarged lenticels were observed with dead (phloem or cortex) tissue beneath them (Fig. 4). The dead tissue was always surrounded by lesion periderms and in two cases by two lesion periderms. P. syringae pv. actinidiae bacteria were found on and inside these lenticels (Fig. 4B to I) as well as in the dead phloem and xylem beneath the lenticels. The bacterium was present in both intercellular and intracellular spaces (Fig. 4D to I).

Artificial $P$. syringae pv. actinidiae infections. All three different inoculation methods proved positive. Typical $P$. syringae pv. actinidiae symptoms were evident after 2 to 3 weeks following after artificial contamination, independently of the methodology and kiwifruit cultivar used.

$P$. syringae pv. actinidiae inoculation of uninjured plants. Brown foliar spots surrounded by a yellow halo and browning of kiwifruit leaf ribs were observed on all plants inoculated by spraying bacterial cells onto uninjured leaves (Fig. 5A). In the laboratory, after $72 \mathrm{~h}$ of incubation at $27 \pm 1^{\circ} \mathrm{C}$ on $\mathrm{KB}$ medium, $98 \%$ of the analyses revealed the presence of a single type of bacterial colony. The strains re-isolated from the inoculated plants were purified and their DNA was submitted to analyses for phytobacterial identification using the same methods as those described above for natural infection. The results confirmed the hypothesis that $P$. syringae pv. actinidiae was responsible for the symptoms recorded on the uninjured kiwifruit plants inoculated. ESEM analyses were carried out to investigate the foliar surface on control leaves and to characterize stomata (Fig. 5B). SEM observation of inoculated leaves revealed numerous bacteria immediately surrounding the stomata and on the stomata themselves. They appeared tightly clustered, like a cap coating and occluding the stomatal aperture (Fig. 5C). TEM observation of foliar sections confirmed the fact that bacteria were localized in the stomata and it appeared clear that they had passed through the opening, acquiring access to the spongy parenchyma (Fig. 5D). Higher magnification-level images revealed that the external bacterial cells were somehow organized and embedded within an extracellular matrix (Fig. 5E). Optical sections of sprayed leaves demonstrated that foliar tissues, both the spongy and the palisade parenchyma, were massively invaded by bacteria (Fig. 5F). Bacterial density inside the leaf was so high that the tissues appeared swollen, thus causing loss of their usual organization (Fig. 5G).

$P$. syringae pv. actinidiae inoculation of injured plants. $P$. syringae pv. actinidiae symptoms were recorded on all kiwifruit leaves inoculated after lesions were provoked (Fig. 6A). SEM analyses of control samples revealed that kiwifruit leaf surface is characterized by polygonal cells and numerous trichomes and hairs (Fig. 6B). The artificially injured epidermis revealed rupture of these structural features in addition to a pronounced modification of the epidermal cells (Fig. 6C). Already within $24 \mathrm{~h}$ after abrasion and inoculation, the presence of bacteria at the base or inside the artificial fissures on the foliar surface was obvious (Fig. 6C). Near a broken trichome, numerous bacteria were found entering the tissue, some of them organized within an extracellular matrix (Fig. 6D). The observation of optical sections of the injured leaves revealed that, as in the previous experiment, once the bacteria entered, the invasion was massive. The mesophyll was completely colonized by $P$. syringae pv. actinidiae cells and the typical structural aspect of the tissue was lost (Fig. 6E).

It was confirmed that both the spongy and palisade parenchyma were infected by bacteria (Fig. 7A and B). At the highest level of magnification, it became clearly visible that bacteria were densely

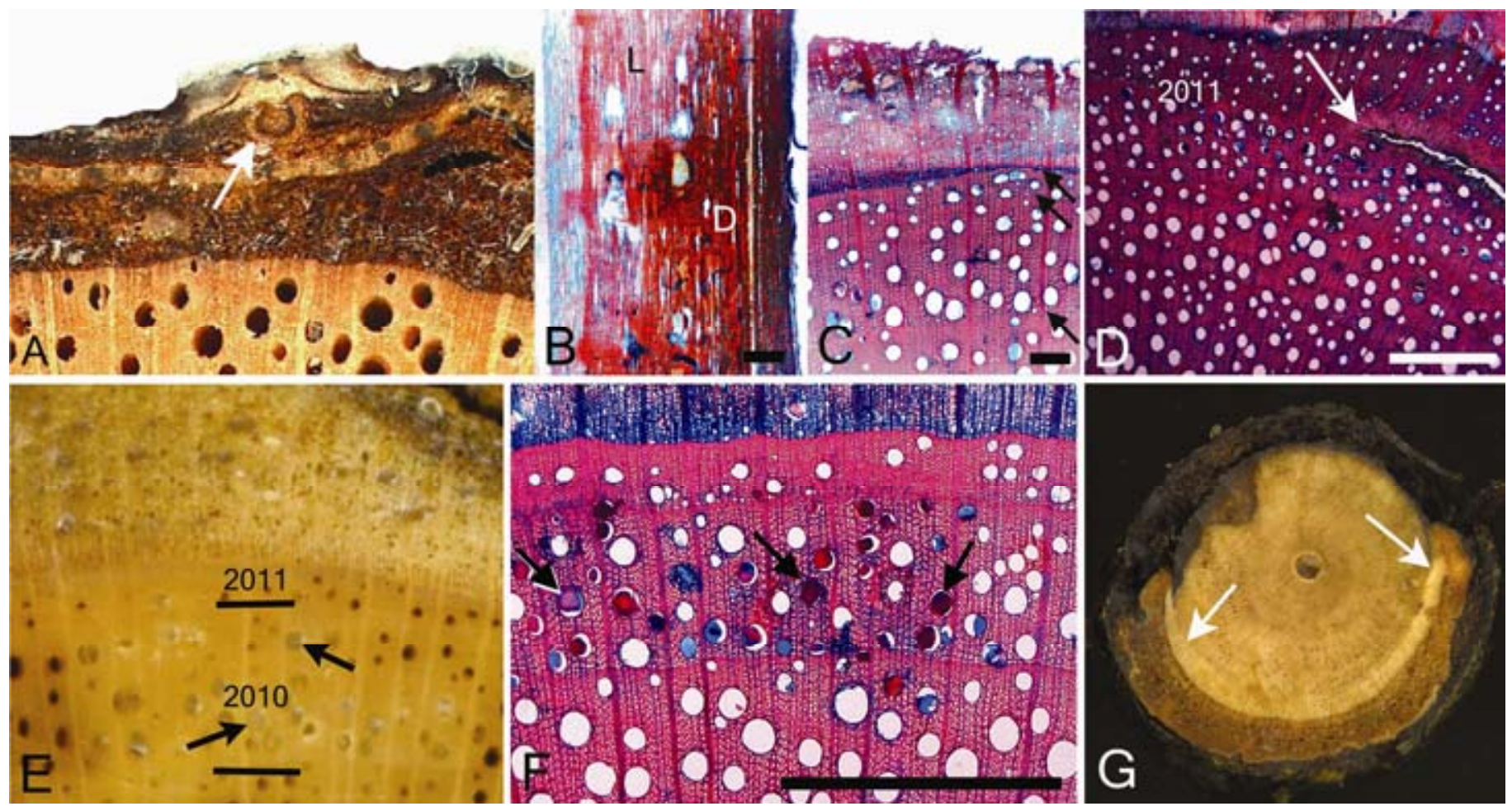

Fig. 3. Symptoms of Pseudomonas syringae pv. actinidiae infection in stems of Actinidia chinensis (A, D, F, and G) and Actinidia deliciosa (B, C, and E). A, Transverse section through the bark and xylem showing a lenticel with a wound periderm (arrow) extending into the cortex of 'Jin Tao'. B, Radial section through living (L) and dead (D) bark tissue of 'Hayward' (scale bar $500 \mu \mathrm{m}$ ). C, Transverse section through a branch with tree ring boundaries (arrows) indicative of 'Hayward' (scale bar $500 \mu \mathrm{m}$ ). D, Transverse thin section showing the edge of callus tissue (arrow) formed after the phloem was infected during the growing season of 2011, leaving a strip of dead cambium as a crack in the wood of 'Hort 16A' (scale bar $2 \mathrm{~mm}$ ). E, Detail of the 2010 and 2011 tree rings that are exceptionally small and contain a considerable quantity of tyloses in the vessels (arrows) of 'Hayward'. F, A thin transverse section showing vessels filled with tyloses (arrows) of 'Hort 16A' (scale bar $2 \mathrm{~mm}$ ). G, Transverse section through a branch, with phloem and cambium dieback around half the circumference, and adjacent lesion reactions (arrows) of 'Hort 16A' 

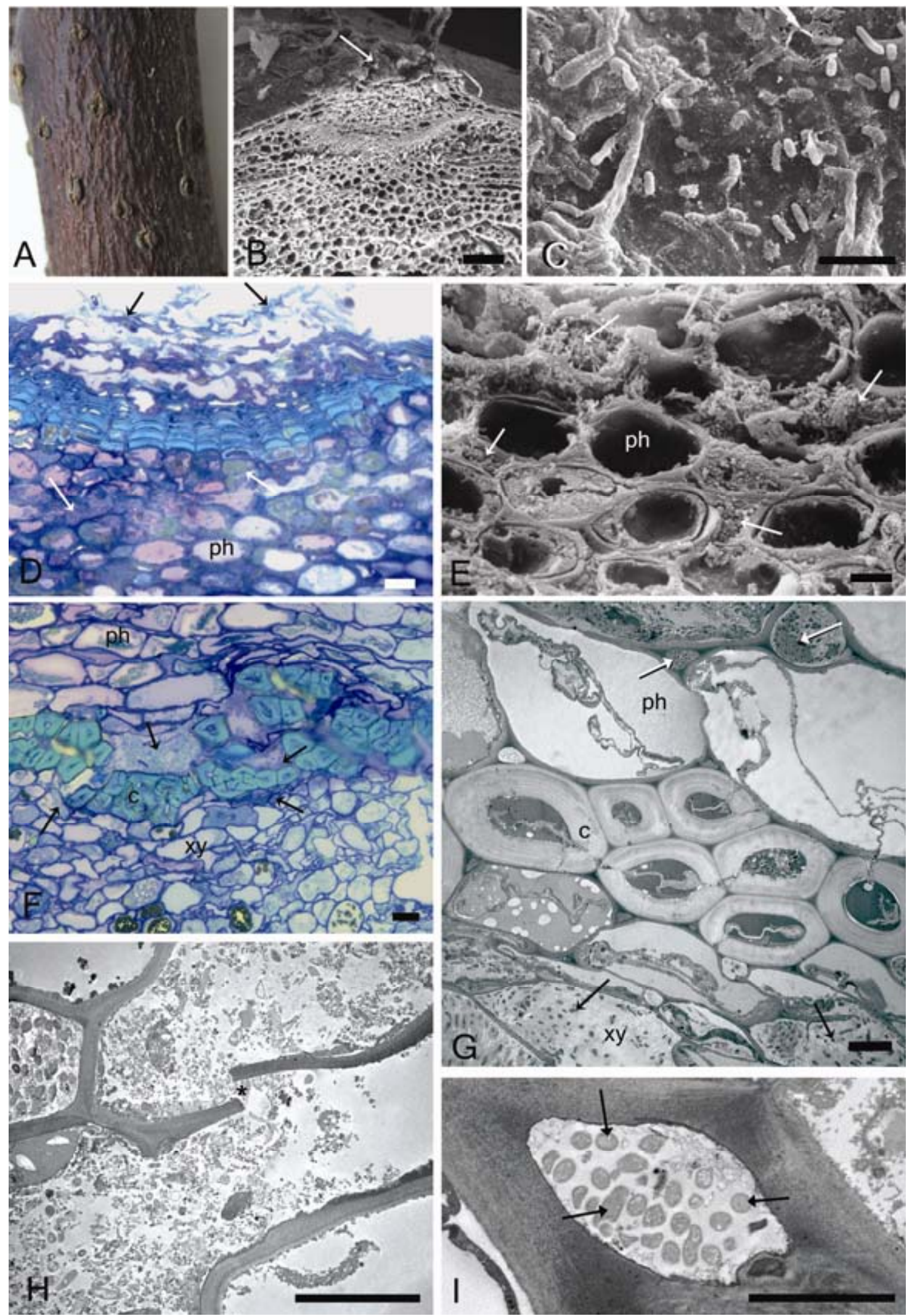

Fig. 4. Lenticels in Actinidia spp. infected with Pseudomonas syringae pv. actinidiae. A, Segment of a branch with lenticels. B, Radial section through the lenticels by scanning electron microscopy (SEM), showing the surface (arrow) and the internal tissues (scale bar $100 \mu \mathrm{m}$ ). C, SEM high magnification of the lenticels surface where bacterial cells of $P$. syringae pv. actinidiae were observed embedded into a dense matrix (scale bar $5 \mu \mathrm{m}$ ). D, Optical radial section of the outermost region, showing that bacteria were present on the surface of (black arrows) and inside the phloem cells (ph), causing tissue disorganization (white arrows); staining with Toluidine colored the bacteria blue: the blue cells were the ones completely invaded by bacteria (scale bar $20 \mu \mathrm{m}$ ). E, SEM view of phloem (ph) with P. syringae pv. actinidiae invading cells and also localized in the extracellular space (arrows) (scale bar $10 \mu \mathrm{m}$ ). F, Optical section of the internal region showing that bacterial cells colonized the phloem (ph) and passed the cambium (c) to invade the xylem (xy, arrows) (scale bar $20 \mu \mathrm{m})$. G, High degree magnification by transmission electron microscopy (TEM) of the internal tissue. P. syringae pv. actinidiae cells were visible both in the phloem (ph) and in the xylem (xy) (arrows); (c) cambium (scale bars $10 \mu \mathrm{m}$ ). H, TEM micrograph with phloem cells infected by bacteria where the cell wall presented rupture (star) (scale bars $10 \mu \mathrm{m}$ ). I, Higher degree magnification showing bacteria (arrows) tightly packed within a xylem cell (scale bars $5 \mu \mathrm{m}$ ). 
packed and immersed within an amorphous matrix (Fig. 7C). Compared with the control sections (Fig. 7D), the morphology of the mesophyll cells in injured leaves presented alterations due also to the presence of the very high number of bacteria invading the intercellular space (Fig. 7A). In the infected palisade and spongy cells, cytoplasmic organelles (i.e., chloroplasts) were not visible and the cell wall was broken in some places, allowing the bacteria to migrate to the bordering cells (Fig. 7C).

$P$. syringae pv. actinidiae inoculation of plants with lesioned base petioles. One week after artificial inoculation, the petioles
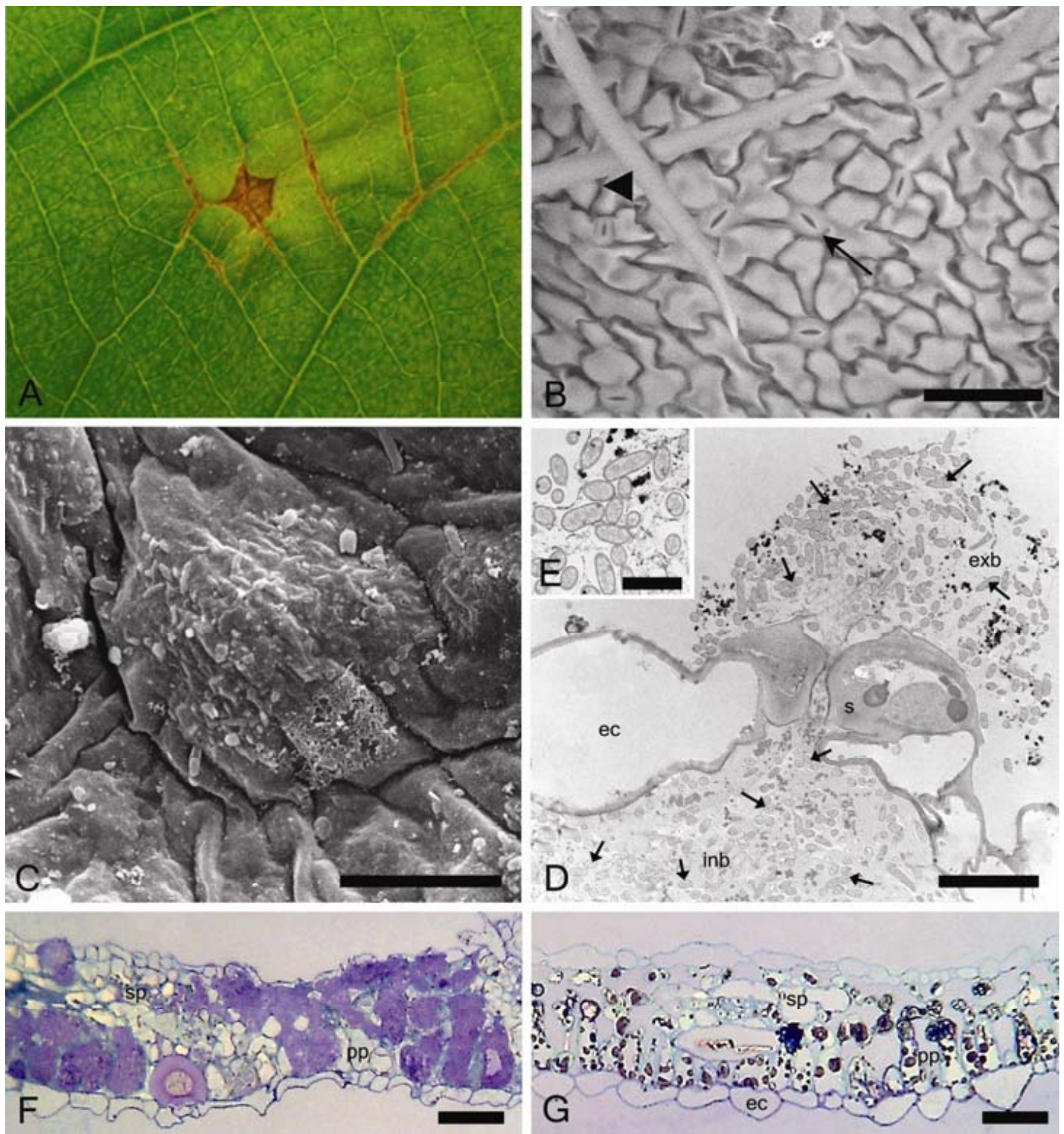

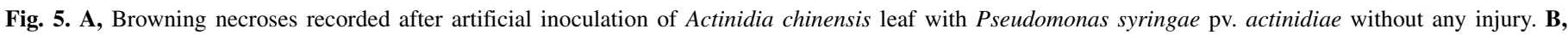
Environmental scanning electron microscopy image of kiwifruit leaf surface where stomata (arrow) and trichomes (arrowhead) were visible (scale bar 100 um). C, Scanning electron microscopy micrograph of bacterial cells of $P$. syringae pv. actinidiae cells on kiwifruit leaf covering the stomata and occluding the stomata aperture, $48 \mathrm{~h}$ after artificial inoculation (scale bar $10 \mu \mathrm{m}$ ). D, A longitudinal section of a stomata as viewed using transmission electron microscopy (TEM), the bacteria (arrows) were localized on the stoma (s) forming a cap (external bacteria, exb) and passed through the opening, invading the spongy parenchyma (internal bacteria, inb) (scale bar $10 \mu \mathrm{m}$ ). E, High magnification by TEM of the external bacterial cells (scale bar $2 \mu \mathrm{m}$ ). F, Optical sections of sprayed leaves where the spongy (sp) and palisade (pp) tissues were massively invaded by bacteria; the Toluidine blue staining conferred a blue coloration on the bacteria and the blue masses showed bacteria tightly packed inside the cells. Because of the high concentration of bacteria in these foliar cells, the tissue lost the typical organization observed in noninfected control sections compared with that in control sections (G) (scale bars $50 \mu \mathrm{m})$. Epidermal cells (ec). 
along with surrounding leaf and stem tissue presented obvious $P$. syringae pv. actinidiae symptoms (Fig. 8A). Morphological analyses of the petiole sections by means of SEM revealed that the tissues were massively colonized (Fig. 8B). The highest concentration of bacteria was observed at the base of the petiole (Fig. 8C) with a progressive decrease in the distal portion (Fig. 8D). Optical sections of proximal part of the petiole showed that the phloem is the area privileged by the pathogen, where it finds suitable conditions to survive and multiply (Fig. 8E and F). The phloem was invaded by the bacteria, which were also seen to pass through the cambium, invading the xylem (Fig. 8E and F). As in the previous experiments, infected cells were completely full of bacteria and the morphology of the cells was altered compared with the control samples (Fig. 8G). At high magnification level, the TEM revealed that the phloem cells with the highest concentration of bacteria presented ruptures of the cell wall
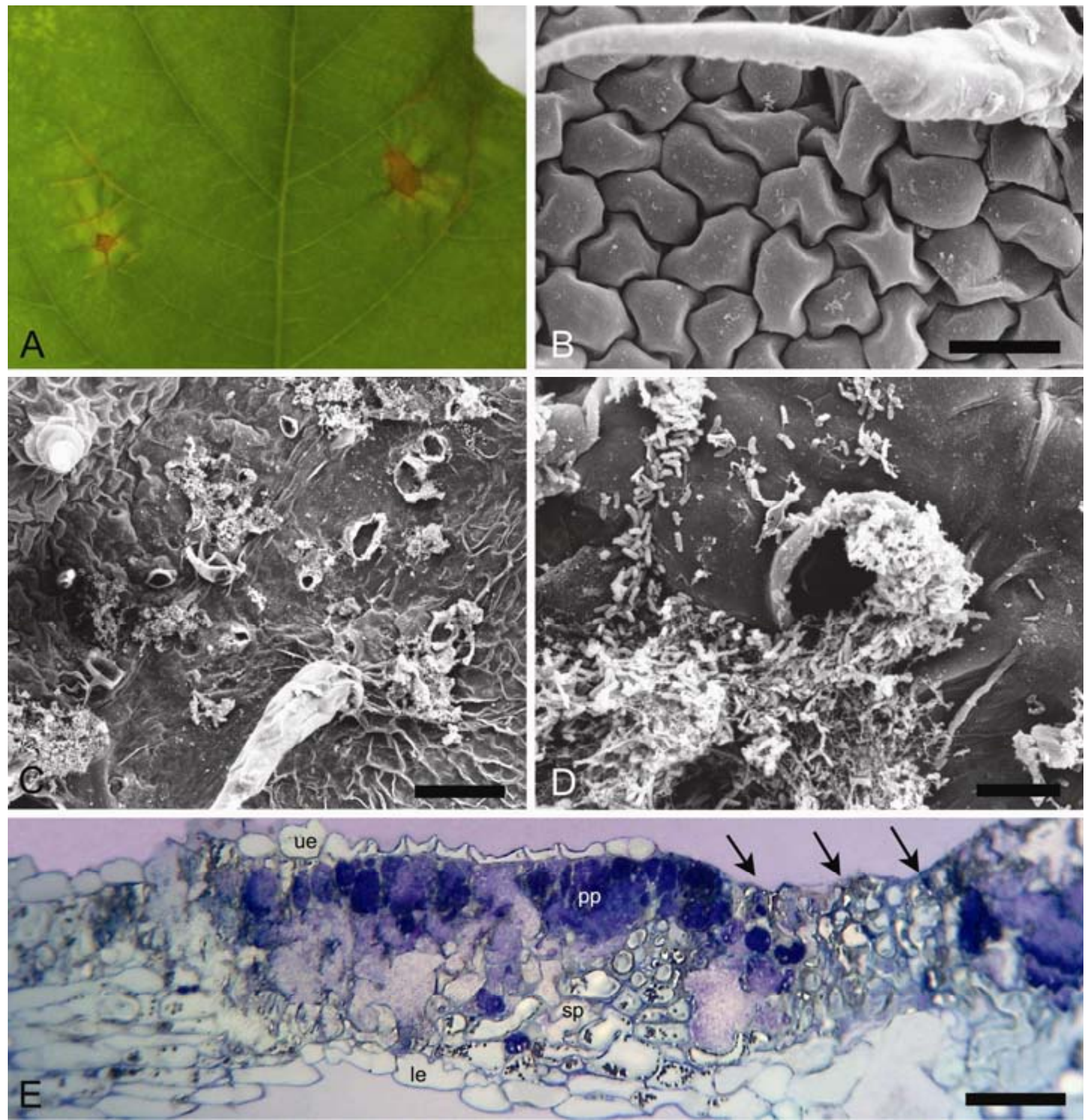

Fig. 6. A, Browning necroses recorded 2 weeks after artificial inoculation of a Actinidia chinensis leaf with Pseudomonas syringae pv. actinidiae by injury. B, Scanning electron microscopy (SEM) image of the control leaf surface, characterized by epidermal polygonal cells and trichomes (scale bar $50 \mu \mathrm{m}$ ). C, After inoculation and artificial injuries, some broken trichomes were revealed by SEM with numerous bacteria at the base or inside the artificial openings on the kiwifruit leaf surface (scale bar $100 \mu \mathrm{m}$ ). D, High magnification of a broken trichome, where the presence of $P$. syringae pv. actinidiae cells entering through the aperture was abundant (scale bar $10 \mu \mathrm{m}$ ). E, Toluidine blue-colored sections of the injured leaves indicating that bacteria invasion was massive. The spongy (sp) and palisade (pp) tissues were colonized by P. syringae pv. actinidiae cells entering the opening (arrows) created by artificially injuring the leaf mechanically prior to spray-inoculation (scale bar $50 \mu \mathrm{m}$ ). Upper epidermis (ue), lower epidermis (le). 
through which the bacteria seemed to spread to adjacent cells (Fig. 8H and I).

\section{DISCUSSION}

At present, the kiwifruit bacterial canker pandemic represents the most devastating disease of kiwifruit in existence. Since 2008 thousands of infected hectares and millions of dollars have been lost causing a severe crisis within the entire worldwide kiwifruit production chain. Consequently, the scientific community feels an urgent need to understand the infection processes and prevent further spread of $P$. syringae pv. actinidiae. Here new insights into how $P$. syringae pv. actinidiae invades kiwifruit plants and how plants respond to $P$. syringae pv. actinidiae invasion have been obtained by combining inoculation experiments with the study of natural infected plants in central Italy.

Based on previous field observations (34), P. syringae pv. actinidiae uses several access routes (natural openings/lesions)
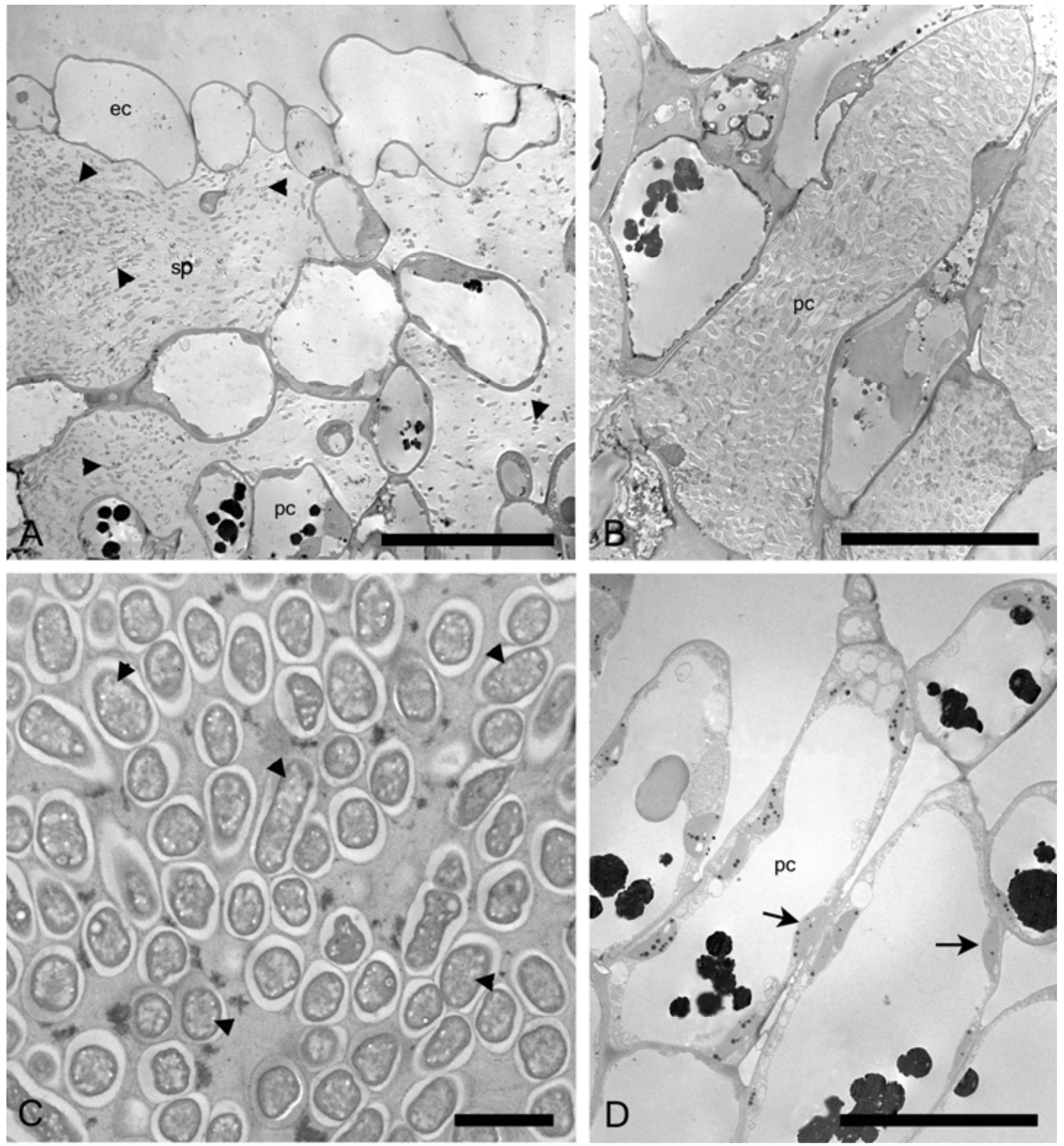

Fig. 7. Transmission electron microscopy micrographs of the foliar tissues in section. A, Invasion of bacteria (arrowheads) observed in the spongy parenchyma (sp); epidermal cells (ec), palisade cells (pc) (scale bar $20 \mu \mathrm{m}$ ). B, Palisade cells (pc) were also strongly infected by Pseudomonas syringae pv. actinidiae cells (scale bar $20 \mu \mathrm{m}$ ). C, Colonization was high and bacteria (arrowheads) were tightly packed and immersed in amorphous matrix inside the cells (scale bar $2 \mu \mathrm{m}$ ). D, Control sections of the mesophyll tissue, with palisade cells where chloroplasts (arrows) were observed (scale bar $20 \mu \mathrm{m}$ ). 

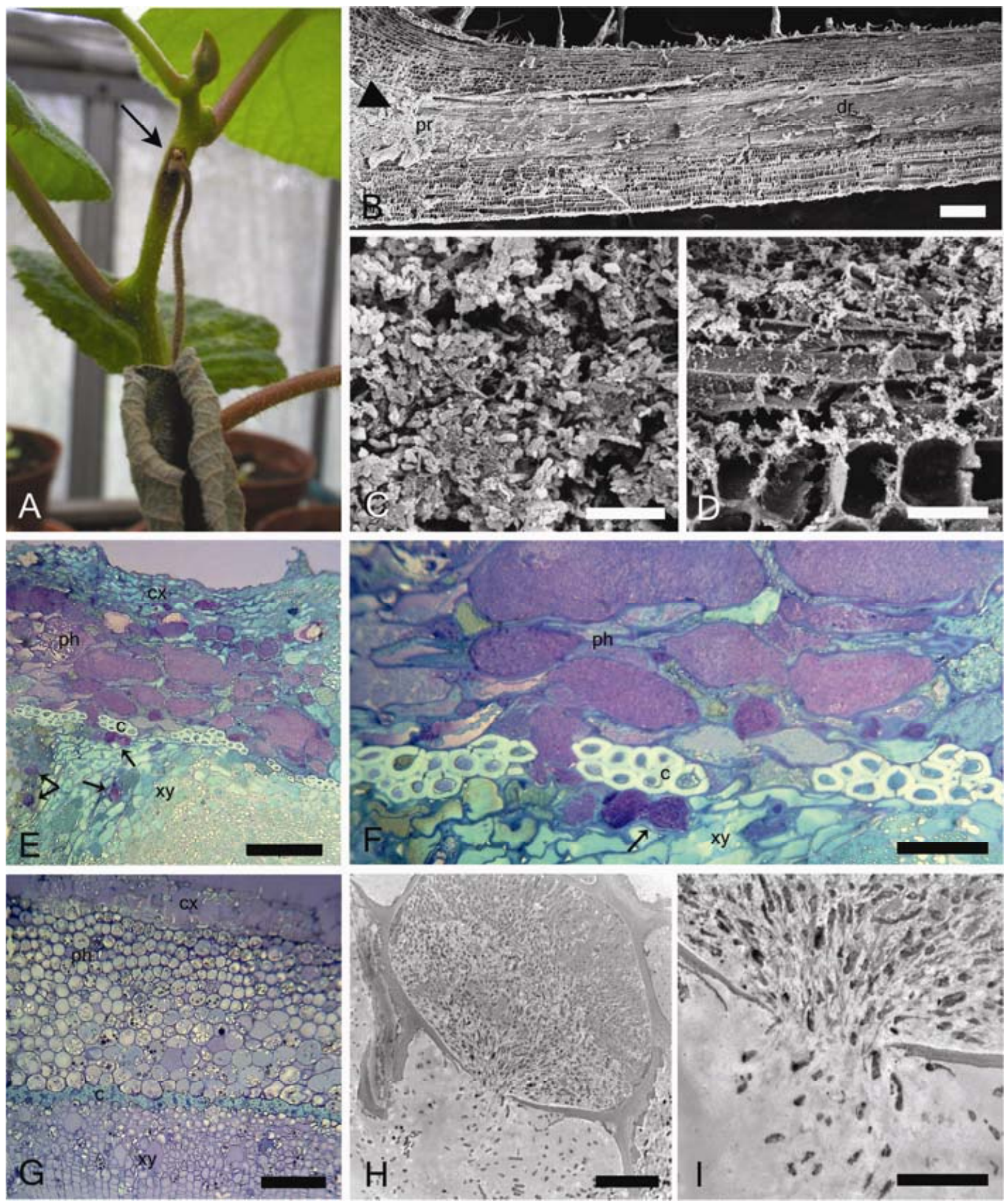

Fig. 8. A, Symptoms on a kiwifruit plant (Actinidia chinensis) 3 weeks after Pseudomonas syringae pv. actinidiae inoculation by injuring at the base of the foliar peduncle. The complete collapse of the peduncle caused complete rolling and death of the leaf as an initial marked dark browning along the kiwifruit stem. B to D, C, Scanning electron microscopy micrographs of the peduncle in section showing heavy bacterial invasion at the base of the peduncle (proximal region, pr, arrow) and $\mathbf{D}$, a progressive decrease in the distal (dr) (scale bars $[\mathbf{B}] 500 \mu \mathrm{m},[\mathbf{C}] 10 \mu \mathrm{m}$, and $[\mathbf{B}] 50 \mu \mathrm{m}$ ). $\mathbf{E}$, An optical section of the proximal part of the peduncle evidencing a heavy infection of the phloem $(\mathrm{ph})$ shown by the blue violet masses stained using Toluidine blue and representing the abnormal phloem cells completely invaded by bacteria. The high concentration of bacteria in this tissue altered the typical organization compared with control sections. Some cells invaded by bacteria (arrows) were also evidenced in the xylem (xy) (scale bar $100 \mu \mathrm{m})$. F, P. syringae pv. actinidiae filled phloem cells and appeared to spread to the xylem (xy) through the cambium (c) (scale bar $40 \mu \mathrm{m}$ ). G, Control section (scale bar $100 \mu \mathrm{m}$ ). Cortex (cx). H, Transmission electron microscopy (TEM) image focusing on a phloem cell (the one indicated by an arrow in F) completely infected by bacteria (scale bar $10 \mu \mathrm{m}$ ). I, TEM high magnification showed $P$. syringae pv. actinidiae bacterial cells able to break the wall of phloem and flow into the adjacent cell (scale bar $5 \mu \mathrm{m}$ ). 
and penetration strategies (9). Considering $P$. syringae pv. actinidiae infections in uninjured plants, different genes might be involved in stomata- $P$. syringae interaction and their role seem to be important in stomatal lock-up, affecting the physiology of the plants, with a decrease in plant growth and yield. Furthermore, stomatal conductance is reduced as the canopy density increases $(35,36,57)$.

Observations of naturally infected kiwifruit plants. No changes in vessel size, vessel density, or ring width were observed in only one season after the onset of $P$. syringae pv. actinidiae infection while clear growth depression and reductions in vessel size appeared after a longer period and in kiwifruit plants more severely infected by. This seems to suggest the existence of a considerable time lag between the initial insurgence of $P$. syringae pv. actinidiae symptoms on leaves and the appearance of changes in the anatomy of the wood. Consequently, it seems to indicate that dendrochronological dating based on growth reduction and vessel characteristics is of little use when tracing the course of initial infection but only provides infos into more advanced states of infection. Further research is required to address and understand this time lag. In general, changes in ring width, average and maximum vessel size, and vessel density are associated with changes in a number of environmental conditions such as drought, defoliation, flooding, and geomorphic processes and may contribute, together with dating of $P$. syringae pv. actinidiae-induced cambial dieback, to understand the development of $P$. syringae $\mathrm{pv}$. actinidiae infection over time $(11,13,21,23)$. In the heavily affected samples, vertical cracks were observed in the bark where red exudates were excreted. These cracks originated from callus and lesion xylem formation on the edges of cambial dieback. We found that the cambium dieback took place during the growing season (2011) a phenomenon shared in cases when similar lesions occur in horse chestnut (Aesculus hippocastanum) infected by $P$. syringae pv. aesculi (60).

In both the A. deliciosa and A. chinensis species, tyloses were frequently observed in the outermost tree rings; in particular, these are generally of the utmost importance to water conductance (71). Tyloses are formed by living parenchyma cells surrounding vessels that cease to function due, for example, to harmful gas embolism or as a defense mechanism used to inhibit the spread of pathogens via the xylem $(10,17,42,62,68,70,71)$. Normally, the formation of tyloses occurs close to the lesion or site of infection (62) which congruent with the formation of tyloses in $A$. chinensis. In Hayward, tyloses were present in most of the plants, suggesting that they were formed indirectly because of a disruption in the hydraulic system due for example, to $P$. syringae pv. actinidiae-induced wilting or used as a defense mechanism to reduce the spread of $P$. syringae pv. actinidiae within the xylem.

Plant invasion via biotic and abiotic openings. Based on the present study, it appears that $P$. syringae pv. actinidiae cells are able to colonize internal tissues of kiwifruit plants by entering through natural openings (stomata, lenticels) and/or through lesions (Figs. 7 and 8).

This agrees with the findings of previous studies $(34,51,52$, $55,56)$; moreover, it is supported by experiments which indicate that $P$. syringae pv. actinidiae is capable of infecting host tissue directly when bacteria like $P$. syringae pv. aesculi $(22)$ is inoculated into young plants. It seems possible that the $P$. syringae pv. actinidiae gains access to stem and branch like leaf scars, growth cracks at branch junction level, dormant buds or lesions, since these act as the entry points for other bacterial tree pathogens all of which require natural openings or unprotected surfaces in order to infect plants (Fig. 9) (12,25).

Considering that $A$. chinensis cultivars are particularly susceptible to frost damage, this might explain why $P$. syringae pv. actinidiae infection in young $A$. chinensis plants causes substantial damage, while in A. deliciosa the progression of the disease in slower and the symptoms less destructive (G. M. Balestra and J. M. Young, personal communication; 24).

Our microscopic observations show that $P$. syringae pv. actinidiae cells invade vessels. Once the bacteria are in the vessels, nutrients existing in the sap probably favor their growth and diffusion along through the stems or pit membranes (14), which might explain why a week or more after infection occlusions are evident throughout stem segments (62).

The presence of $P$. syringae pv. actinidiae bacteria in both lenticels and underlying dead phloem and even xylem tissue confirms the importance of lenticels as a gateway by which to infect kiwifruit plants. As lenticels have numerous intercellular spaces that permit the entry of air through the periderm, this most
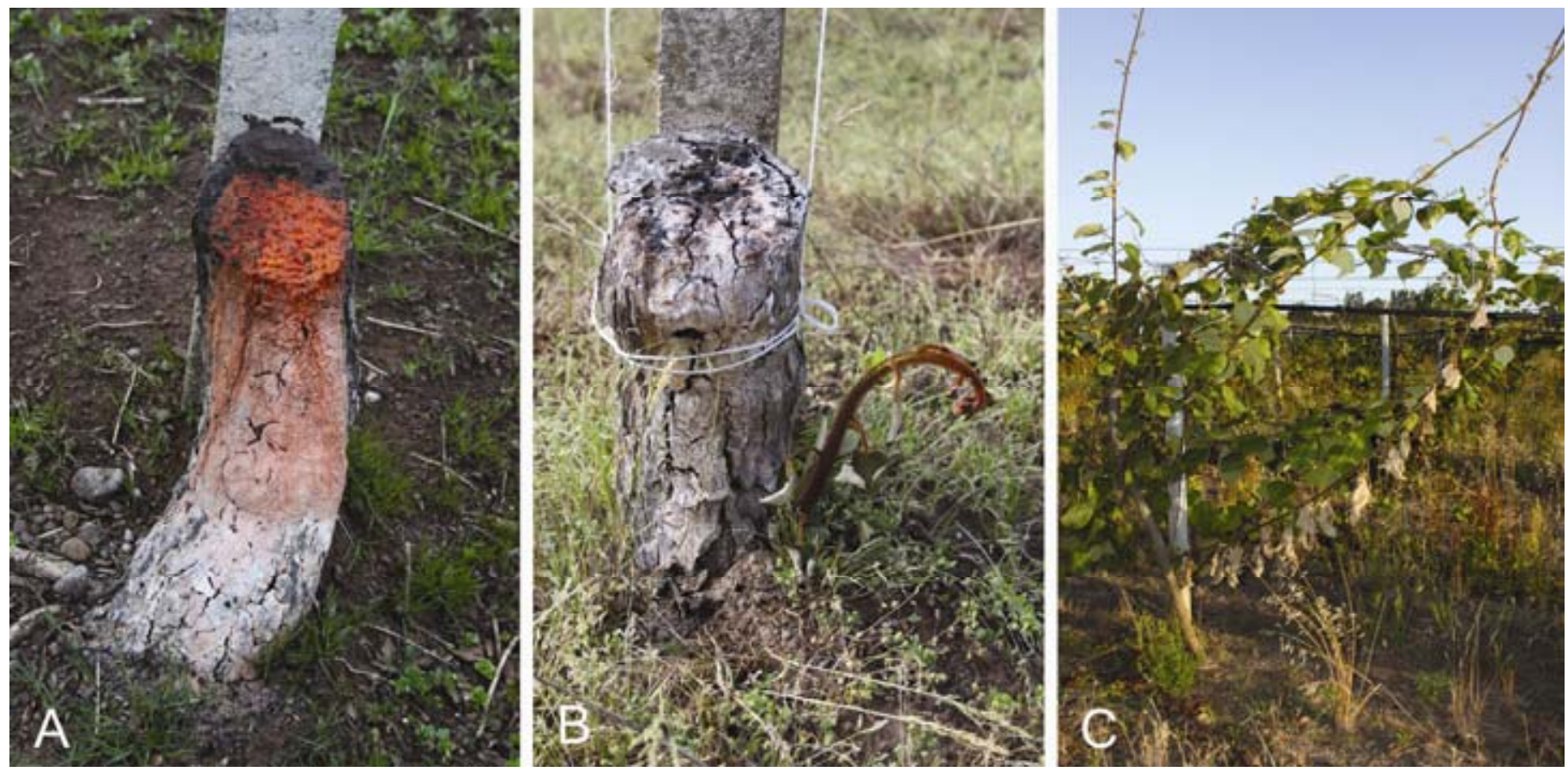

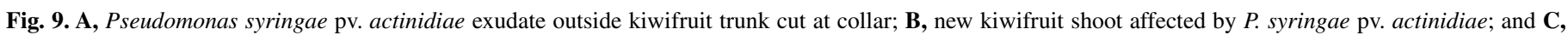
young cane developed from kiwifruit trunk infected by $P$. syringae pv. actinidiae. 
probably offers easy access to $P$. syringae pv. actinidiae (23). So far there is only one other pseudomonad pathogen that is known to infect its host via lenticels: the closely related $P$. syringae pv. aesculi pathogen (60). Steele and colleagues suggest that infection via lenticels may not be normal for diseases caused by Pseudomonas spp. This is confirmed by Serizawa and colleagues (56) who proved unsuccessful when inoculating lenticels of $A$. deliciosa with $P$. syringae pv. actinidiae. In addition, lenticels were much more abundant in A. chinensis than in A. deliciosa plants; in the case of branches, these anatomical structures determine a higher number of holes, showing significant differences in resistance to kiwifruit bacterial canker (30).

The detection of $P$. syringae pv. actinidiae in naturally infected lenticel as well as in underlying phloem and xylem tissue shows that $P$. syringae pv. actinidiae is probably capable to infect all kind of plant tissue. The formation of multiple lesion periderms aimed to compartmentalizing $P$. syringae pv. actinidiae-infected phloem tissue shows that the kiwifruit plant appears incapable of coping with $P$. syringae pv. actinidiae. Our results support the view that it is mandatory to develop cultivars with fewer lenticels and stomata (29-31). In accordance with our results, horse chestnuts present similar lesion periderms below lenticels (60). The presence of double lesion periderms in kiwifruit plants suggests that the formation of a (suberized) lesion periderm is not sufficient to cope with the bacterium (60).

The finding that $P$. syringae pv. actinidiae bacteria can colonize the xylem of kiwifruit plants complies with findings concerning many Pseudomonas species found in trees in general (60).

$\boldsymbol{P}$. syringae pv. actinidiae grows within a biofilm. The existence of a matrix (biofilm) surrounding $P$. syringae pv. actinidiae bacteria and its likely involvement in different (external and internal) phases of infection (Figs. 4 to 6) are congruent with previous studies $(37,41)$. According to previous research, the biofilm enclosing $P$. syringae pv. actinidiae cells favors their adaptation to and competition within the host environment (37). Moreover, control strategies should address the creation of specific compounds that cope with $P$. syringae pv. actinidiae biofilm formation in a such way as to determine vascular parameters (i.e., $\mathrm{pH})$ unfavorable to the biological cycle of the pathogen.

When biofilm reaches maturation an intercellular signaling system (quorum sensing) is activated, allowing the bacteria to regulate the expression of specific sets of genes, such as virulence factors, and those associated with resistance to antimicrobial compounds and the host defense mechanisms (43). It has already been shown that biofilms are able to influence many metabolic processes including several of the pathogenic steps involved in $P$. syringae infection processes $(45,66)$. Environmental conditions may also be related to genes and their expression and, while in the case of $P$. syringae pv. actinidiae these aspects still need to be investigated, for other bacterial plant pathogens (Xylella fastidiosa, $P$. syringae) they appear to be associated with an increase in environmental adaptation and competitive capacities $(32,37,38,41,43,58)$.

We have also discovered that $P$. syringae pv. actinidiae bacteria live within biofilm during their biological life, both outside and inside host plants.

Conclusions. In this study we have shown that $P$. syringae pv. actinidiae bacteria can infect both the phloem and xylem of kiwifruit plants. Dendrochronological measurements of ring width, vessel size, and vessel density are of no use during the first year after the onset of $P$. syringae pv. actinidiae symptoms, suggesting the likely existence of a time lag of at least 1 year between initial $P$. syringae pv. actinidiae symptoms and datable reduction in growth and vessel size. By dating $P$. syringae pv. actinidiae-induced cambial dieback we found that cambial dieback occurs during the growing season.

By applying experimental $P$. syringae pv. actinidiae inoculation, we have shown that $P$. syringae pv. actinidiae infection may be propagated through natural openings (lenticels, stomata) and lesions.

Important efforts to effectively combat the bacterial canker of kiwifruit are being made all over the world. Breeding programs aimed to producing $P$. syringae pv. actinidiae-resistant kiwifruit germplasm have begun. At present, no sources of resistance to the most common cultivars have been identified in Europe while there are scientific reports of the development of a $P$. syringae pv. actinidiae-resistant germplasm in China (29-31).

\section{ACKNOWLEDGMENTS}

The present research was financed by the Italian Ministery of Agriculture's Food and Forestry Policy (MIPAAF) OIGA n. 247, and in part by the Department of Agriculture, of the Lazio Region. We thank C. E. Morris (INRA-PACA, F) and B. A. Vinatzer (Virginia Tech, USA) for their critical review and appraisal of this paper, C. Salvatici (CEME CNR, Florence, I) for the ESEME analyses effectuated, M. C. Taratufolo (DAFNE, University of Tuscia, Viterbo, I) for the technical provided during the $P$. syringae pv. actinidiae artificial contaminations procedures, and G. Lucci for his technical assistance in the field. We also thank M. Decuyper and U. Sass-Klaassen (Wageningen University, NL) for their help in carrying out the anatomical analyses. We thank the C.T. de Wit Graduate School for Production Ecology and Resource Conservation for the funding granted to P. Copini.

\section{LITERATURE CITED}

1. Anonymous. 2011. Bacterial canker, kiwifruit-Chile: First report (O'Higgins, Maule), Published online by the International Society for Infectious Diseases. Archive no. 20110325.0940. http://www. promedmail.org/pls/apex/f?p=2400:1001:::NO::F2400_P1001_BACK_PA GE,F2400_P1001_PUB_MAIL_ID: 1000,87723

2. Balestra, G. M., Mazzaglia, A., Spinelli, R., Graziani. S, Quattrucci, A., and Rossetti, A. 2008. Cancro batterico su Actinidia chinensis. L'Inform. Agrario 38:75-76.

3. Balestra, G. M., Mazzaglia, A., Quattrucci, A., Renzi, M., and Rossetti, A. 2009. Current status of bacterial canker spread on kiwifruit in Italy. Austral. Plant Dis. Note 4:34-36.

4. Balestra, G. M., Renzi, M., and Mazzaglia, A. 2010. First report of bacterial canker of Actinidia deliciosa caused by Pseudomonas syringae pv. actinidiae in Portugal. New Dis. Rep. 22:10.

5. Balestra, G. M., Renzi, M., and Mazzaglia, A. 2011. First report of Pseudomonas syringae pv. actinidiae on kiwifruit plants in Spain. New Dis. Rep. 24:10.

6. Balestra, G. M., and Varvaro, L. 1998. Seasonal fluctuations in Kiwifruit phyllosphere and ice nucleation activity of Pseudomonas viridiflava. J. Plant Pathol. 80:151-156.

7. Baştaş, K. K., and Karakaya, A. 2012. First report of bacterial canker of kiwifruit caused by Pseudomonas syringae pv. actinidiae in Turkey. Plant Dis. 96: 452

8. Biosecurity Australia. 2011. Pest risk analysis report for Pseudomonas syringae pv. actinidiae associated with Actinidia (kiwifruit) propagative material. Department of Agriculture, Fisheries and Forestry, Canberra.

9. Bostock, R. M., and Sterner, B. A. 1989. Perspectives and wound healing in resistance to pathogen. Annu. Rev. Phytopathol. 27:343-371.

10. Clerivet, A., Deon, V., and Alami, I. 2000. Tyloses and gels associated with cellulose accumulation in vessels are responses of plane tree seedlings (Platanus $\times$ acerifolia) to the vascular fungus Ceratocystis fimbriata f. sp. platani. Trees-Structure Function 15:25-31.

11. Corcuera, L., Camarero, J. J., and Gil-Pelegrin, E. 2004. Effects of a severe drought on growth and wood anatomical properties of Quercus faginea. IAWA J. 25:185-204.

12. Crosse, J. E. 1955. Bacterial canker of stone-fruits. I. Field observations on the avenues of autumnal infection of cherry. J. Hort. Sci. 30:131.

13. den Ouden, J., Sass-Klaassen, U., and Copini, P. 2007. Dendrogeomorphology-A new tool to study drift-sand dynamics. Netherlands J. Geosci. 86:355-363.

14. Dimond, A. E. 1970. Biophysics and biochemistry of the vascular wilt syndrome. Annu. Rev. Phytopathol. 8:301-322.

15. Di Marco, S., Calzarano, F., Osti, F., and Mazzullo, A. 2004. Pathogenicity of fungi associated with a decay of kiwifruit. Austral. Plant Pathol. 33:337-342.

16. Di Marco, S., and Osti, F. 2008. Foliar symptom expression of wood decay in Actinidia deliciosa in relation to environmental factors. Plant Dis. 92:1150-1157. 
17. Elgersma, D. M. 1983. Host-parasite interactions in Dutch elm disease. Research on Dutch elm disease in Europe. D. A. Burdek, ed. Proc. EEC Res. Seminar For. Comm. London, Bulletin 60:7881.

18. EPPO, Reporting Service. 2011. First report of Pseudomonas syringae pv. actinidiae in Switzerland 2011/168(8):2.

19. Everett, K. R., Taylor, R. K., Romberg, M. K., Rees-George, J., Fullerton, R. A., Vanneste, J. L., and Manning, M. A. 2011. First report of Pseudomonas syringae pv. actinidiae causing kiwifruit bacterial canker in New Zealand. Austral. Plant Dis. Notes 6:67-71.

20. Fang, Y., Zhu, X., and Wang, Y. 1990. Preliminary studies on kiwifruit diseases in Hunan Province. Sichuan Fruit Sci. Technol. 18:28-29.

21. Fonti, P., von Arx, G., García-González, I., Eilmann, B., Sass-Klaassen, U., Gärtner, H., and Eckstein, D. 2010. Studying global change through investigation of the plastic responses of xylem anatomy in tree rings. New Phytol. 185:42-53.

22. Green, S., Studholme, D. J., Laue, B. E., Dorati F., Lovell, H., Arnold, D., Cottrell, J. E., Bridgett, S., Blaxter, M., Huitema, E., Thwaites, R., Sharp, P. M., Jackson, R. W., and Kamoun, S. 2009. Comparative genome analysis provides insights into the evolution and adaptation of Pseudomonas syringae pv. aesculi on Aesculus hippocastanum. PlosOne 5:e10224. doi:10.1371/journal.pone.0010224

23. Groh, B., Hübner, C., and Lendzian, K. J. 2002 Water and oxygen permeance of phellems isolated from trees: The role of waxes and lenticels. Planta 215:794-801.

24. Kay, C. 2011. Leaf structures, cultivars and Psa. Zespri Kiwifruit J. 4.

25. Kennelly, M. M., Cazorla, F. M., de Vicente, A., Ramos, C., Sundin, G. W. 2007 Pseudomonas syringae diseases of fruit trees: Progress toward understanding and control. Plant Dis. 91:4-17.

26. King, E. D., Ward, M. K., and Raney, D. E. 1954. Two simple media for the demonstration of pyocyanin and fluorescin. J. Lab. Clin. Med. 44:301307.

27. Koh, Y. J., and Nou, I. S. 2002. DNA markers for identification of Pseudomonas syringae pv. actinidiae. Mol. Cells 13:309-314.

28. Lee, Y. H., Jee, J. H., Cha, H. K., Ko, J. S., and Park, K. B. 2001. Occurrence of Phytophthora root rot on kiwifruit in Korea. Plant Pathol. J. 13:154-158.

29. Li, M., Tan, G., Li, Y., Cheng, H., Qiu, K., and Han, X. 2005. Invertase and alpha-amylase activities and their relationship with bacterial canker (Pseudomonas syringae pv. actinidae) in different cultivars of Chinese gooseberry fruit. Plant Physiol. Comm. 41:148-152.

30. Li, M., Tan, G., Li, Y., and Xue, L. 2005. Resistance mechanism of kiwifruit cultivars to Pseudomonas syringae pv. actinidae. Acta Phytophylactica Sin. 32:37-42.

31. Li, Y., Cheng, H., Fang, S., and Qian, Z. 2001. Ecological factors affecting prevalence of kiwifruit bacterial canker and bacteriostatic action of bactericides on Pseudomonas syringae pv. actinidae. Chinese J. Appl. Ecol. 12: 359-362

32. Marques, L. L. R., Ceri, H., Manfio, G. P., Reid, D. M., and Olson, M. E. 2002. Characterization of biofilm formation by Xylella fastidiosa in vitro. Plant Dis. 86:633-638.

33. Mazzaglia, A., Renzi, M., Rossetti, A., Taratufolo, M. C., and Balestra, G. M. 2011. Tecniche di campo e nutrizione contro il cancro del kiwi. L'Inform. Agrario 10:64-67.

34. Mazzaglia, A., Renzi, M., Taratufolo, M. C., Gallipoli, L., Bernardino, R., Ricci, L., Quattrucci, A., Rossetti, R., and Balestra, G. M. 2010. Cancro batterico dell'actinidia: Il punto della situazione in Italia. Riv. Frutticoltura 9:66-76.

35. Melotto, M., Underwood, W., Koczan, J., Nomura, K., and Yang He, S. 2006. Plant stomata function in innate immunity against bacterial invasion. Cell 126:969-980.

36. Melotto, M., Underwood, W., and Yang, He, S. 2008. Role of stomata in plant innate immunity and foliar bacterial diseases. Annu. Rev. Phytopathol. 46:101-122.

37. Morris, C. E., and Monier, J. M. 2003. The ecological significance of biofilm formation by plant-associated bacteria. Annu. Rev. Phytopathol. 41:429-453.

38. Morris, C. E., Monier, J. M., and Jacques, M. A. 1998. A technique to quantify the population size and composition of the biofilm component in communities of bacteria in the phyllosphere. Appl. Environ. Microbiol. 64:4789-4795

39. Mugnai, L., Graniti, A., and Surico, G. 1999. Esca (black measles) and brown wood streaking: Two old and elusive disease of grapevine. Plant Dis. 8:404-418

40. Nishizawa, K., Hirano, M., Kimura, A., Mochizuki, T., Yamamoto, Y., Yamamura, S., and Momose, Y. 1998. Evaluation of the antimicrobial activity of carbapenem and cephem antibiotics against Pseudomonas aeruginosa isolates from hospitalized patients. J. Infect. Chemo. 4:174176.

41. O’Toole, G., Kaplan, H. B., and Kolter, R. 2000. Biofilm formation as microbial development. Annu. Rev. Microbiol. 54:49-79.
42. Pearce, R. B. 1996. Antimicrobial defences in the wood of living trees. New Phytol. 132:203-233.

43. Prigent-Combaret, C., Vidal, O., Dorel, C., and Lejeune, P. 1999. Abiotic surface sensing and biofilm-dependent regulation of gene expression in Escherichia coli. J. Bacteriol. 181:5993-6002.

44. Quattrucci, A., Renzi, M., Rossetti, A., Ricci, L., Taratufolo, M. C., Mazzaglia, A., and Balestra, G. M. 2010. Cancro batterico del kiwi verde: Nuove strategie di controllo. L'Inform. Agrario 16:53-58.

45. Quiñones, B., Dulla, G., and Lindow, S. E. 2005. Quorum sensing regulates exopolysaccharide production, motility, and virulence in Pseudomonas syringae. Mol. Plant-Microbe Interact. 18:682-693.

46. Rees-George, J., Vanneste, J. L., Cornish, D. A., Pushparajah, I. P. S., Yu, J., Templeton, M. D., and Everett, K. R. 2010. Detection of Pseudomonas syringae pv. actinidiae using polymerase chain reaction (PCR) primers based on the 16S-23S rDNA intertranscribed spacer region and comparison with PCR primers based on other gene regions. Plant Pathol. 59:453-464.

47. Rossetti, A., and Balestra, G. M. 2008. Pseudomonas syringae pv. syringae on kiwifruit plants: Epidemiological traits and its control. Pages 65-68 in: Pseudomonas syringae Pathovars and Related PathogensIdentification, Epidemiology and Genomics. M. Fatmi, A. Collmer, N. S. Iacobellis, J. W. Mansfield, J. Murillo, N. W. Schaad, and M. Ullrich, eds. Springer, the Netherlands.

48. Schneuwly, D. M., and Stoffel, M. 2008. Tree-ring based reconstruction of the seasonal timing, major events and origin of rockfall on a case-study slope in the Swiss Alps. Nat. Hazards Earth Syst. Sci. 8:203-211.

49. Scortichini, M. 1994. Occurrence of Pseudomonas syringae pv. actinidiae on kiwifruit in Italy. Plant Pathol. 43:1035-1038.

50. Scweingruber, F. H. 1996. Tree Rings and Environment: Dendroecology. Berne Haupt Publishers, Berne, Switzerland.

51. Serizawa, S., and Ichikawa, T. 1993. Epidemiology of bacterial canker of kiwifruit. 1. Infection and bacterial movement in tissue of new canes. Ann. Phytopathol. Soc. Japan 59:452-459.

52. Serizawa, S., and Ichikawa, T. 1993. Epidemiology of bacterial canker of kiwifruit. 2. The most suitable times and environments for infection on new canes. Ann. Phytopathol. Soc. Japan 59:460-468.

53. Serizawa, S., and Ichikawa, T. 1993. Epidemiology of bacterial canker of kiwifruit. 3. The seasonal changes of bacterial population in lesions and its exudation from lesion. Ann. Phytopathol. Soc. Japan 59:469-476.

54. Serizawa, S., and Ichikawa, T. 1993. Epidemiology of bacterial canker of kiwifruit. 4. Optimum temperature for disease development on new canes. Ann. Phytopathol. Soc. Japan 59:694-701.

55. Serizawa, S., Ichikawa, T., and Suzuki, H. 1994. Epidemiology of bacterial canker of kiwifruit. 5. Effect of infection in fall to early winter on the disease development in branches and trunk after winter. Ann. Phytopathol. Soc. Japan 60:237-244.

56. Serizawa, S., Ichikawa, T., Takikawa, Y., Tsuyumu, S., and Goto, M. 1989. Occurrence of bacterial canker of kiwifruit in Japan: Description of symptoms, isolation of the pathogen and screening of bactericides. Ann. Phytopathol. Soc. Japan 55:427-443.

57. Smith, G. S., Gravett, T. M., Edwards, C. M., Curtis, J. P., and Buwalda, J. G. 1994. Spatial analysis of the canopy of kiwifruit vines as it relates to the physical, chemical and postharvest attributes on the fruit. Ann. Bot. 73:99-111

58. Souza, A. A., Takita, M. A., Coletta-Filho, H. D., Caldana, C., Goldman, G. H., and Yanai, G. M. 2003. Analysis of gene expression in two growth states of Xylella fastidiosa and its relationship with pathogenicity. Mol. Plant-Microbe Interact. 16:867-875.

59. Sperry, J. S., Donnelly, J. R., and Tyree, M. T. 1988. A method for measuring hydraulic conductivity and embolism in xylem. Plant, Cell Environ. 11:35-40

60. Steele, H., Laue, B. E., and Mac Askill, G. A. 2010. Analysis of the natural infection of European horse chestnut (Aesculus hippocastanum) by Pseudomonas syringae pv. aesculi. Plant Pathol. 59:1005-1013.

61. Stefani, E., and Giovanardi, D. 2011. Dissemination of Pseudomonas syringae pv. actinidiae through pollen and its epiphytic life on leaves and fruits. Phytopathol. Mediter. 50:489-496.

62. Sun, Q., Rost, T. L., and Matthews, M. A. 2008. Wound-induced vascular occlusions in Vitis vinifera (Vitaceae): Tyloses in summer and gels in winter. Am. J. Bot. 95:1498-1505.

63. Takikawa, Y., Serizawa, S., and Ichikawa, T. 1989. Pseudomonas syringae pv. actinidiae pv. nov.: The causal bacterium of canker of kiwifruit in Japan. Ann. Phytopathol. Soc. Japan 55:437-444.

64. Vanneste, J. L., Poliakoff, F., Audusseau, C., Cornish, D., Paillard, S., Rivoal, C., and Yu, J. 2011. First report of Pseudomonas syringae pv. actinidiae the causal agent of bacterial canker of kiwifruit on Actinidia deliciosa in France. Plant Dis. 95:1311.

65. Varvaro, L., and Fabi, A. 1992. The role of ice nucleation active Pseudomonas viridiflava in frost injury to kiwifruit plants. Riv. Patol. Veg. 2:85-90. 
66. Von Bodman, S. B., Bauer, W. D., and Coplin, D. L. 2003. Quorum sensing in plant-pathogenic bacteria. Annu. Rev. Phytopathol. 41:12.112.28 .

67. Wang, Z., Tang, X., and Liu, S. 1992. Identification of the pathogenic bacterium for bacterial canker on actinidia in Sichuan. Journal of Southwest Agricultural University 06.

68. Windt,C. W., Vergeldt, F. J., de Jager, P. A., and Van As, H. 2006. MRI of long-distance water transport: a comparison of the phloem and xylem flow characteristics and dynamics in poplar, castor bean, tomato and tobacco. Plant Cell Environ. 29:1715-1729.

69. Young, J. M., Cheesmur, G. J., Welham, F. V., and Henshall, W. R. 1988. Bacterial blight of kiwifruit. Ann. Appl. Biol. 112:91-105.

70. Zimmerman, M. H. 1983. Xylem Structure and Ascent of Sap. SpringerVerlag, Berlin.

71. Zimmerman, M. H., Brown, C. L., and Tyree, M. T. 1971. Trees: Structure and Function. Springer, New York. 